\title{
ANALISIS KEPUTUSAN PEMBELIAN ULANG AXIS DITINJAU DARI BAURAN PEMASARAN KASUS DI KOTA PADANG
}

\author{
Riri Mayliza \\ Sekolah Tinggi Ilmu Ekonomi “KBP” Padang \\ ririmayliza@akbpstie.ac.id
}

\begin{abstract}
ABSTRAK
Perilaku konsumen tidak hanya pada keputusan pembelian akan tetapi diikuti pula oleh tahap perilaku purnabeli (post purchase behavior). Pada tahap ini konsumen akan merasakan tingkat kepuasan atau ketidakpuasan tertentu yang akan mempengaruhi perilaku berikutnya. Kepuasan konsumen akan tercipta, jika produsen kartu seluler AXIS mampu memenuhi harapan yang dimiliki oleh para konsumennya. Salah satu alternatif yang dapat digunakan produsen AXIS dalam upaya menciptakan kepuasan bagi para konsumennya adalah menggunakan bauran pemasaran yang mencakup produk, harga, promosi dan saluran distribusi dalam strategi pemasaran produknya. Oleh karena itu, tujuan penelitian ini adalah untuk menganalisis pengaruh produk, harga, promosi dan saluran distribusi terhadap kepuasan konsumen dalam hal keputusan pembelian ulang AXIS secara simultan dan parsial. Penelitian ini juga bertujuan untuk mengkaji dari variabel-variabel tersebut yang memiliki pengaruh dominan terhadap kepuasan konsumen AXIS. Jenis penelitian ini adalah kausatif, dengan populasi penelitian konsumen pembeli kartu seluler AXIS. Berdasarkan perhitungan dengan menggunakan rumus Slovin diperoleh sampel penelitian 100 responden. Data penelitian dikumpulkan dengan menggunakan kuesioner dan wawancara. Uji validitas dan reliabilitas digunakan untuk mengukur setiap item variabel penelitian. Analisis data dilakukan dengan menggunakan metode statistik deskriptif untuk mendeskripsikan variabel penelitian dan teknik analisis regresi berganda, dengan F-test dan t-test untuk menguji pengaruh variabel-variabel independen terhadap variabel dependen. Berdasarkan hasil analisis regresi diperoleh bahwa : 1) Dari hasil penelitian diketahui bahwa variabel produk berpengaruh signifikan terhadap keputusan pembelian ulang AXIS di Kota Padang. Pengaruh ini ditunjukkan oleh nilai t-hitung lebih besar dari nilai t-tabel. 2) Dari hasil penelitian diketahui bahwa variabel harga berpengaruh signifikan terhadap keputusan pembelian ulang AXIS di Kota Padang. Pengaruh ini ditunjukkan oleh nilai t-hitung lebih besar dari nilai t-tabel. 3) Dari hasil penelitian diketahui bahwa variabel promosi berpengaruh signifikan terhadap keputusan pembelian ulang AXIS di Kota Padang. Pengaruh ini ditunjukkan oleh nilai t-hitung lebih besar dari nilai t-tabel. 4) Dari hasil penelitian diketahui bahwa variabel distribusi berpengaruh signifikan terhadap keputusan pembelian ulang AXIS di Kota Padang. Pengaruh ini ditunjukkan oleh nilai t-hitung lebih besar dari nilai t-tabel.
\end{abstract}

Kata Kunci: Keputusan Pembelian Ulang, Bauran Pemasaran 


\section{PENDAHULUAN}

Perilaku konsumen akan selalu mengalami perubahan dalam meng konsumsi suatu barang atau jasa. Konsumen akan lebih berfikir terhadap hal-hal seperti kemudahan, biaya dan hal yang praktis dalam memperoleh suatu barang atau jasa serta keuntungan lain yang diperoleh dari barang atau jasa. Banyak pilihan mengakibatkan konsumen lebih mempertimbangkan terlebih dahulu sebelum melakukan pembelian terhadap barang atau jasa. Dimana perilaku konsumen adalah tindakan konsumen dalam menda patkan, mengkonsumsi, dan mengha biskan produk atau jasa, termasuk proses keputusan yang mendahului dan menyusul tindakan ini (Setiadi, 2003:3).

Saat ini terdapat banyak sekali persaingan antar perusahaan industri seluler. Diantara begitu banyaknya perusahaan seluler tersebut, salah satunya adalah AXIS. Sebuah seluler yang murah, akses internet yang cepat, dan bisa memenuhi keinginan konsumen untuk mengakses berbagai program aplikasi adalah dambaan setiap orang. Terlebih lagi bagi para siswa yang masih bersekolah dan para mahasiswa yang notabenenya harus dapat hidup hemat namun tetap dapat berkomunikasi dengan lancar sesamanya. Untuk itu dalam berkomunikasi mereka membutuhkan produk yang dapat membantu mereka dalam berkomunikasi dengan harga yang terjangkau.

Menyadari keinginan dan kebutuhan dari konsumen tersebut AXIS muncul sebagai kartu seluler yang baru dengan harga yang terjangkau. AXIS memberikan kemu dahan dari segi harga kartu perdana yang begitu murah dan juga membe rikan harga yang terjangkau untuk setiap pengisian ulang pulsanya.

Hal yang sama tentu juga diharap kan oleh kebanyakan masyarakat di Kota Padang yang pada umumnya dipe nuhi oleh para pelajar dan mahasiswa yang berasal dari berbagai daerah di Sumatera Barat yang juga mengi nginkan kartu seluler yang berkualitas dengan harga yang terjangkau. Khusus di Asia terutama di Indonesia sebagian besar konsumen memiliki keterbatasan daya beli, dimana konsumen mengi nginkan produk dengan harga murah tapi berkualitas.

\section{TINJAUAN PUSTAKA DAN HIPOTESIS Definisi Pemasaran}

Pemasaran merupakan suatu kegiatan yang dilakukan perusahaan untuk mempertahankan hidup usahanya, untuk mendapatkan laba, untuk me ngembangkan, untuk mendapatkan nilai dari usahanya serta memenuhi kebu tuhan konsumen dengan memberikan rasa puas terhadap produk yang di berikan.

Menurut Kotler (2005:8) mengemu kakan bahwa definisi pema saran adalah: "Suatu proses sosial dan manajerial yang di dalamnya individu dan kelom pok mendapatkan apa yang mereka butuhkan dan inginkan, dengan mencip takan, menawarkan dan memper tukar kan produk yang bernilai dengan pihak lain".

\section{Pengertian Manajemen Pemasaran}

Manajemen sebagai seni dan ilmu untuk memilih pasara sasaran serta menda patkan, menjaga, dan menambah jumlah pelanggan melalui penciptaan, penye rahan dan pengkomunikasian nilai pelanggan yang unggul.

Sedangkan Manajemen Pemasa ran menurut Kotler (2005:9) yaitu :

"Manajemen pemasaran dapat diartikan sebagai proses perencanaan dan pelaksa naan pemikiran, penetapn harga, promosi, serta penyaluran gagasan, barang dan jasa untuk menciptakan pertukaran yang sasaran-sasarannya individu dan organisasi”.

Kegiatan pemasaran hendaknya dilakukan dengan filosofi yang telah dipikirkan secara matang tentang pemasaran yang efisien, efektif, dan bertanggung jawab sosial. 


\section{Bauran Pemasaran}

Para pemasar menggunakan sejumlah alat untuk mendapatkan keinginan dari pasar sasaran mereka, alat-alat itu membentuk suatu pemasaran. Menurut Kotler (2005:7) Bauran pemasaran (Marketing Mix) adalah "seperangkat alat pemasaran yang diguna-kan perusahaan secara terus menerus untuk mencapai tujuan pemasarannya dalam pasar sasaran. Bauran perusahaan merupakan seperangkat alat pemasaran taktik yang dapat dikendalikan berupa produk, harga, promosi dan distribusi. Program pemasaran efektif mencampurkan semua elemen bauran pemasaran kedalam program yang terko-ordinasi yang dirancang untuk mencapai pasar sasaran perusahaan sehingga dapat menyerahkan nilai kepada konsumen.

\section{Konsep Produk}

Produk merupakan salah satu variabel penting dalam bauran pemasaran (marketing mix) yang harus diperhatikan perusahaan. Di dalam variabel ini perusahaan akan memilih jenis produk atau jasa yang akan diproduksi dan dipasarkan yang mencakup juga segi kualitas, rancangan, bentuk, merek, harga, kemasan serta kemampuan untuk memberikan kepuasan kepada pemakainya. Menurut Kotler (2005:69), pengertian produk adalah "Segala sesuatu yang dapat ditawarkan ke pasar untuk memuaskan keinginan dan kebutuhan konsumen yang meliputi barang fisik, jasa, pengalaman, acara-acara, orang, tempat, properti, organisasi, dan gagasan."

\section{Konsep Harga}

Pengertian harga menurut Kotler dan Amstrong (2001:439) adalah "Sejumlah uang yang dibebankan atas suatu produk atau jasa, atau jumlah dari nilai yang ditukar konsumen atas manfaat-manfaat karena memiliki atau menggunakan produk atau jasa tersebut." Selain itu harga juga merupa-kan nilai yang dipertukarkan konsumen untuk suatu manfaat atas pengkonsumsian, penggunaan atau kepemilikan barang atau jasa. Jadi harga tidak selalu berbentuk uang karena harga bisa berbentuk tenaga, waktu, dan keahlian.

Sedangkan menurut Tjiptono (1997:149), "Harga bisa diungkapkan dengan berbagai istilah misalnya iuran, tarif, sewa, bunga, premium, upah, gaji, dan lain-lain sebagai-nya." Dari sudut pandang pemasaran, harga merupakan satuan moneter atau ukuran lainnya (termasuk barang dan jasa lainnya) yang ditukarkan agar memperoleh hak kepemilikan atau penggunaan suatu barang atau jasa.

\section{a. Peran Harga}

Tingkatan harga yang ditetapkan suatu perusahaan akan mempengaruhi kuantitas produk yang terjual. Selain itu secara tidak langsung harga juga mempengaruhi biaya karena kuantitas yang terjual berpengaruh pada biaya yang ditimbulkan dalam kaitannya dengan efisiensi produksi. Oleh karena itu, penetapan harga mempengaruhi pendapatan total dan biaya total, maka keputusan dan strategi penetapan harga memegang peranan penting dalam setiap perusahaan.

Sementara itu dari sudut konsumen, harga sering sekali digunakan sebagai indikator nilai bilamana harga tersebut dihubungkan dengan manfaat yang dirasakan atas sesuatu barang atau jasa. Menurut Tjiptono (1997:151), "Nilai (value) dapat didefenisikan sebagai rasio atas manfaat yang dirasakan terhadap harga."

\section{b. Penetapan Harga}

Suatu perusahaan harus menetapkan harga untuk pertama kali ketika perusahaan tersebut mengembangkan produk baru ketika perusahaan memperkenalkan produk 
regulernya ke saluran distribusi atau daerah baru. Oleh karena itu, perusahaan harus memutuskan dimana ia akan memposisikan produknya berdasarkan mutu dan harga.

Perusahaan harus mempertim bangkan berbagai faktor dalam menetapkan kebijak-sanaan harga. Menurut Kotler (2005:142) ada enam langkah untuk menetapkan harga, yaitu:

1) Memilih tujuan penetapan harga

2) Menentukan permintaan

3) Memperkirakan biaya

4) Menganalisis biaya, harga dan tawaran pesaing

5) Memilih metode penetapan harga

6) Memilih harga akhir

\section{Konsep Promosi}

Dengan dilakukannya kegiatan promosi perusahaan mengaharapkan adanya pening-katan angka penjualan dan keuntungan.

Menurut Swastha (1999:338), "Promosi adalah kombinasi strategi yang paling baik dari variabel-variabel periklanan, penjualan personal dan alat promosi yang lain, yang semuanya direncanakan untuk mencapai program penjualan.

Menurut Kotler (2005:65), "Promosi adalah suatu program terpadu dari metode komunikasi material perusahaan atau produk yang dapat memuaskan konsumen, mendorong penjualan, serta memberi konstribusi pada kinerja laba perusahaan". Kotler (2005:65) mengemukakan "Promosi merupakan upaya membujuk orang untuk menerima produk, konsep dan gagasan".

Dari kerangka teoritis di atas, maka hipotesis penelitian adalah produk, harga, promosi dan saluran distribusi berpengaruh signifikan terhadap kepuasan konsumen dalam hal keputusan pembelian ulang AXIS di kota Padang.

\section{METODE PENELITIAN \\ Jenis Penelitian}

Penelitian ini dilakukan untuk mengetahui variabel produk, harga, promosi dan distribusi berpengaruh terhadap keputusan pembelian ulang AXIS. Sehubungan dengan penelitian tersebut maka dalam pelaksanaan penelitian ini peneliti menggunakan penelitian jenis kausatif. Menurut Umar (2000: 37) penelitian kausatif bertujuan untuk menganalisis hubungan antara satu variabel dengan variabel lainnya.

\section{Objek Penelitian}

Penelitian ini dilaksanakan di Kota Padang, khususnya pada konsumen AXIS dengan asumsi-asumsi dan kriteria-kriteria tertentu selama melakukan penelitian untuk mendapatkan kevalidan data.

\section{Populasi dan Sampel}

1. Populasi

Menurut Umar (2000:78) populasi adalah semua individu yang dijadikan subjek penelitian untuk memperoleh informasi yang sesuai dengan tujuan penelitian. Dalam penelitian ini yang menjadi populasi adalah seluruh konsumen yang pernah membeli dan menggunakan AXIS di Kota Padang yang diperkirakan berjumlah kurang lebih 1.200 orang.

2. Sampel

Adapun dalam penelitian ini menggunakan sampel yang mana hanya meneliti dari sebagian hasil populasi. Dengan rumus Slovin : 


$$
\begin{aligned}
& n=\frac{N}{1+N(e)^{2}} \\
& \mathrm{n}=\frac{1.200=92,31 \% \text { diambil100 sampe }}{1+1.200(0,01)}
\end{aligned}
$$

Untuk pemilihan sampel dilakukan dengan cara accidental sampling. Jadi dapat disimpulkan bahwa jumlah sampel dalam penelitian ini adalah 100 orang.

\section{Definisi dan Operasional Variabel}

Definisi operasional dalam penelitian ini sangat diperlukan untuk memberikan gambaran yang jelas agar tidak menimbulkan persepsi yang berbeda terhadap permasalahan yang dibahas. Penelitian ini terdiri dari variabel terikat (dependent variable) keputusan pembe lian ulang yang diberi notasi (Y) dan variabel bebas (independent variable) adalah Produk (X1), Harga (X2), Promosi (X3) dan Distribusi (X4). Defenisi Variabel yang akan diteliti adalah sebagai berikut:

\section{Produk}

Produk dimaksudkan adalah penilaian konsumen atas semua karakteristik atau ciriciri yang melekat pada AXIS. Indikator meliputi merek desain produk, kepraktisan dan kemudahan produk, produk yang inovatif, memberikan berbagai fasilitas yang menjanjikan dalam penggunaan produknya.

\section{Harga}

Harga adalah penilaian konsumen atas sejumlah nilai yang dipertu karkan untuk suatu manfaat yang diperoleh dari AXIS Indikator yang meliputi keterjangkauan harga AXIS, harga yang cukup bersaing, kesesuaian harga dengan kualitas, dan kesesuauian harga dengan harga pasar dalam kategori kartu seluler.

\section{Promosi}

Promosi adalah penilaian konsumen dengan tujuan memperkenalkan, menciptakan suatu ransangan dan terwu judnya suatu kepercayaan atas suatu informasi sehingga mampu untuk menciptakan perilaku kearah yang posi tif tentang AXIS ke konsumen yang dinyatakan dalam Skala Likert. Untuk menggambarkan variabel ini digunakan indikator yang meliputi iklan pada AXIS yang cukup menarik dan inovatif.

\section{Distribusi}

Distribusi adalah kegiatan yang dilakukan oleh pemasar dalam menyalurkan barang atau produk dari produsen sampai ketangan konsumen AXIS. Adapun indikator dari distribusi yang akan dijadikan dalam penelitian ini adalah saluran, persediaan, dan lokasi.

\section{Keputusan Pembelian Ulang}

Keputusan pembelian ulang adalah perilaku pembelian yang pernah dilakukan konsumen terhadap AXIS dan akan membeli lagi untuk kedua atau ketiga kalinya. Untuk menggambarkan variabel ini digunakan indikator yang meliputi frekuensi pembelian dan volume pembelian. Keputusan Pembelian Ulang diukur dengan menggunakan skala likert-5.

\section{Teknik Analisis Data}

Teknik analisa data dalam penelitian ini merupakan salah satu strategi yang menjadi kunci pokok dalam keberhasilan penelitian. Analisis dalam penelitian ini dilakukan dalam beberapa teknis analisa yang perhitungannya menggunakan bantuan komputer program SPSS versi 16.0. 
Untuk keperluan analisa data, penelitian ini menggunakan beberapa teknik analisa statistik seperti statistik deskriptif, uji validitas dan reliabilitas, uji Asumsi, uji koefisien korelasi, uji regresi linier sederhana dan berganda, serta uji regresi linier bertingkat. Berikut ini akan dijelaskan masing-masing alat statistik tersebut sebagai berikut :

Umar (2000:285), statistik deskriptif merupakan statistik yang menggam barkan fenomena yang menarik perhatian yang meliputi transformasi data mentah ke dalam bentuk yang akan memberi informasi untuk menjelaskan sekumpulan faktor dalam suatu situasi. Sedangkan menurut Sugiyono (2003: 172) statistik deskriptif adalah metode statistik yang digunakan untuk menggam barkan atau mendeskripsikan data yang telah dikumpulkan menjadi sebuah infor masi, misalnya mendeskripsikan profil responden (Jenis Kelamin, Pendidikan, Usia, dll), nilai rata-rata variabel penelitian dan distribusi frekuensi jawaban responden terhadap masing-masing pertanyaan pada variabel penelitian.

\section{Uji Validitas}

Suatu instrumen dikatakan valid jika instrumen ini mampu mengukur apa saja yang hendak diukurnya dan mampu mengungkapkan apa saja yang ingin diungkapkan. Besarnya $r$ tiap butir pernyataan dapat dilihat dari hasil analisis SPSS pada kolom Corrected items total correlation. Kriteria uji validitas secara singkat (rule of tumb) adalah 0,3. Jika korelasi sudah lebih besar dari 0,3, pernyataan yang dibuat dikategorikan shahih/valid (Umar, 2000).

\section{Uji Reliabilitas}

Pengujian reliabilitas ini hanya dilakukan terhadap butir-butir yang valid, yang diperoleh melalui uji validitas. Selanjutnya untuk melihat tingkat reliabilitas data, SPSS memberikan fasilitas untuk mengukur reliabilitas, jika cronbach alpha $>0,6$ maka reliabilitas pertanyaan bisa diterima (Umar, 2000).

\section{Uji Regresi Berganda}

Umar (2000:299), analisa regresi berganda merupakan teknik statistik yang digunakan untuk menguji pengaruh beberapa variabel bebas terhadap variabel terikat. Tujuan menggunakan analisa regresi berganda dalam penelitian ini adalah untuk mengetahui pengaruh Produk (X1), Harga (X2), Promosi (X3) dan Distribusi (X4) terhadap Keputusan Pembelian Ulang (Y) masyarakat di Kota Padang baik secara parsial maupun secara simultan.

Adapun persamaan regresi linear berganda dalam penelitian ini dapat dilihat sebagai berikut:

$\mathrm{Y}=\mathrm{a}+\mathrm{b} 1 \mathrm{X} 1+\mathrm{b} 2 \mathrm{X} 2+\mathrm{b3X3}+\mathrm{b} 4 \mathrm{X} 4+\mathrm{e}$

Dimana:

Y $\quad=$ Keputusan Pembelian Ulang

a $\quad=$ konstanta

$\mathrm{b} \quad=$ Koefisien regresi

$\mathrm{X} 1 \quad=$ Produk

$\mathrm{X} 2=$ Harga

$\mathrm{X} 3=$ Promosi

$\mathrm{X} 4=$ Distribusi

\section{Uji Hipotesis}

Hipotesis dapat diartikan sebagai suatu pernyataan yang masih lemah kebenarannya dan perlu dibuktikan atau dugaan yang sifatnya masih sementara. Hipotesis statistik akan diterima jika hasil pengujian membenarkan pernya taannya dan 
akan ditolak jika terjadi penyangkalan dari pernyataannya. Dalam pengujian hipotesis, keputusan yang dibuat mengandung ketidak pastian, artinya keputusan bisa benar atau salah, sehingga menimbulkan resiko.

\section{Uji t}

Uji t bertujuan untuk mengetahui besarnya pengaruh masing-masing variabel independen secara individual (parsial) terhadap variabel dependen (Umar, 2000). Hasil uji ini pada output SPSS dapat dilihat pada tabel Coefficients. Nilai dari uji t dapat dilihat dari t-value (pada kolom sig) dengan pengujian hipotesis sebagai berikut :

1. Ho diterima jika t-hitung < t-tabel, atau nilai $\mathrm{p}$-value pada kolom sig. >level of significant yang menyatakan adanya pengaruh yang tidak signifikan antara bauran pemasaran terhadap keputusan pembelian ulang AXIS.

2. Ho diterima jika t-hitung > t-tabel, atau nilai p-value pada kolom sig. < level of significant yang menyatakan adanya pengaruh yang signifikan antara bauran Uji F pemasaran terhadap keputusan pembelian ulang AXIS.

Uji simultan dengan F-test bertujuan untuk mengetahui pengaruh bersama-sama variabel independen terhadap variabel dependen (Umar, 2000). Hasil F-test ini pada output SPSS dapat dilihat pada tabel ANOVA. Hasil F-Test menunjukkan variabel independen secara bersama-sama berpengaruh terhadap variabel dependen jika f-value (pada kolom Sig) lebih kecil dari level of significant yang ditentukan atau F-hitung (pada kolom F) lebih besar dari F-tabel. F-tabel dihitung dengan cara df1 = k-1, dan df $2=n-k, k$ adalah jumlah variabel dependen dan independen dengan pengujian hipotesis sebagai berikut :

1. Ho diterima jika F-hitung, F-tabel, atau nilai f-value pada kolom sig . level of significant yang menyatakan adanya pengaruh yang tidak signifikan antara bauran pemasaran terhadap keputusan pembelian ulang AXIS.

2. Ha diterima jika F-hitung > F-tabel, atau nilai f-value pada kolom sig < level of significant yang menyatakan adanya pengaruh yang signifikan antara bauran pemasaran terhadap keputusan pembe lian ulang AXIS.

\section{HASIL DAN PEMBAHASAN \\ Hasil Penelitian}

Dalam penelitian ini, data yang dianalisis diperoleh dari kuesioner yang telah disebarkan kepada konsumen AXIS di kota Padang yang pernah menggunakan dan mengisi ulang AXIS. Dalam hal ini saya menggunakan 100 orang responden sesuai dengan rumus slovin.

\section{Gambaran Umum Profil Responden}

Karakteristik responden dalam penelitian ini meliputi jenis kelamin, pendidikan, yang pernah menggunakan dan mengisi ulang AXIS. Karakteristik responden tersebut diuraikan sebagai berikut:

1. Karakteristik responden berdasarkan jenis kelamin

Hasil penelitian terhadap 2 kelompok responden, yaitu laki-laki dan perempuan yang seluruhnya berjumlah 100 responden disajikan dalam tabel sebagai berikut:

\section{Tabel 1}

Karakteristik responden berdasarkan jenis kelamin

\begin{tabular}{|c|l|c|c|}
\hline No. & Jenis Kelamin & Frekuensi & Persentase \\
\hline 1 & Laki-laki & 32 & $32,0 \%$ \\
\hline
\end{tabular}




\begin{tabular}{|c|c|c|c|}
\hline 2 & Perempuan & 68 & $68,0 \%$ \\
\hline \multicolumn{2}{|c|}{ Total } & $\mathbf{1 0 0}$ & $\mathbf{1 0 0 \%}$ \\
\hline
\end{tabular}

Sumber : Hasil Analisis 2013

Berdasarkan data pada tabel 4.2 dapat dilihat bahwa responden yang berjenis kelamin laki-laki sebanyak 32 orang atau $32,0 \%$ sedangkan untuk responden yang berjenis kelamin perempuan $68,0 \%$ atau 68 orang. Dengan melihat data tersebut maka persentase terbesar adalah kelompok yang berjenis kelamin perempuan yaitu sebesar $68,0 \%$.

2. Karakteristik berdasarkan umur

Hasil penelitian terhadap 100 orang responden berdasarkan kelompok umur dapat dilihat pada tabel berikut ini:

Tabel 2.

Karakteristik responden berdasarkan kelompok umur

\begin{tabular}{|c|l|c|c|}
\hline No. & Kelompok Umur & Frekuensi & Persentase \\
\hline 1 & $<19$ Tahun & 40 & $40,0 \%$ \\
\hline 2 & $20-25$ Tahun & 33 & $33,0 \%$ \\
\hline 3 & $25-30$ Tahun & 16 & $16,0 \%$ \\
\hline 4 & $>30$ Tahun & 11 & $11,0 \%$ \\
\hline \multicolumn{2}{|c|}{ Total } & $\mathbf{1 0 0}$ & $\mathbf{1 0 0 , 0 \%}$ \\
\hline
\end{tabular}

Sumber : Hasil Analisis Data 2013

Dari Tabel 2, disimpulkan sebagian besar responden adalah berumur kurang dari 19 Tahun yaitu sebanyak 40 orang (40\%), kemudian responden yang berumur antara 20 - 25 tahun sebanyak 33 orang (33\%), dan responden yang berumur antara 25 30 tahun sebanyak 16 orang $(16 \%)$. Sedangkan responden yang berumur lebih dari 30 tahun hanya 11 otang (11\%). Hal ini menunjukkan bahwa sebagian besar konsu men yang menjadi responden adalah remaja.

3. Karakteristik berdasarkan pekerjaan

Hasil penelitian terhadap 100 orang respon den berdasarkan pekerjaan dapat dilihat pa da tabel berikut ini :

Tabel 3.

Karakteristik responden berdasarkan pekerjaan

\begin{tabular}{|c|l|c|c|}
\hline No. & \multicolumn{1}{|c|}{ Pekerjaan } & Frekuensi & Persentase \\
\hline 1 & Pelajar & 35 & $35,0 \%$ \\
\hline 2 & Mahasiswa & 42 & $42,0 \%$ \\
\hline 3 & Pegawai Negeri Sipil & 9 & $9,0 \%$ \\
\hline 4 & Swasta & 14 & $14,0 \%$ \\
\hline \multicolumn{2}{r}{ Total } & $\mathbf{1 0 0}$ & $\mathbf{1 0 0 , 0 \%}$ \\
\hline
\end{tabular}

Sumber : hasil analisis data 2013

Berdasarkan data pada tabel 3, maka dapat disimpulkan sebagian besar responden ada lah berprofesi mahasiswa yaitu sebanyak 42 orang (42\%), kemudian responden yang berprofesi sebagai pelajar yaitu sebanyak 35 orang (35\%), dan responden yang berprofesi sebagai karyawan swasta sebanyak 14 orang (14\%). Sedangkan responden yang berprofesi sebagai pegawai negeri sipil yaitu sebanyak 9 orang (9\%). Hal ini menunjuk kan bahwa sebagian besar responden adalah berprofesi mahasiswa.

\section{Pengujian Instrumen Penelitian}


Setelah data mentah diolah, maka perlu dilakukan pengujian instrumen penelitian, yaitu pengujian validitas dan reliabilitas. Suatu instrumen dikatakan valid apabila instrumen ini mampu mengukur apa saja yang diungkapkan, sedangkan reliabilitas mengukur sejauh mana suatu instrumen dapat memberikan hasil pengukuran yang konsisten dari waktu ke waktu.

\section{Uji Validitas}

Uji validitas digunakan untuk mengetahui sejauhmana tingkat kevalidan butir-butir pertanyaan dari data yang telah diperoleh dari jawaban responden terhadap kuesioner pada atribut-atribut yang dimiliki oleh AXIS. Dengan level of significan $95 \%$ atau 0,05 . Uji taraf signifikasi ialah jika $r$ hitung $>r$ tabel, maka valid. Sebaliknya jika $r$ hitung < $\mathrm{r}$ tabel maka tidak valid.

Tabel 4.

Validitas item

\begin{tabular}{|c|l|c|c|c|}
\hline No. & \multicolumn{1}{|c|}{ Variabel } & $\begin{array}{c}\text { Jumlah } \\
\text { Item }\end{array}$ & $\begin{array}{c}\text { Item } \\
\text { valid }\end{array}$ & $\begin{array}{c}\text { Item tidak } \\
\text { valid }\end{array}$ \\
\hline 1 & Produk & 18 & 13 & 5 \\
\hline 2 & Harga & 6 & 6 & - \\
\hline 3 & Promosi & 18 & 14 & 4 \\
\hline 4 & Distribusi & 6 & 6 & - \\
\hline 5 & Keputusan Pembelian Ulang & 10 & 10 & - \\
\hline
\end{tabular}

Sumber : Data primer diolah, 2013

Dalam penelitian ini pengujian validitas dilakukan setelah kuesioner dibagikan kepada 100 orang konsumen. Dari rangkuman hasil validitas diatas, butir-butir yang valid dapat dilihat pada pengolahan hasil SPSS 16 pada item total statistic pada kolom corrected item total correlation untuk masing-masing butir pertanyaan adalah sebagai berikut:

Tabel 5

Hasil Uji Validitas Produk

\begin{tabular}{|l|l|l|l|l|}
\hline No. & Pernyataan & R Hitung & R Tabel & Keterangan \\
\hline 1 & Merek AXIS mudah diingat & 0,488 & 0,3 & Valid \\
\hline 2 & Merek AXIS terkenal & 0,071 & 0,3 & Tidak Valid \\
\hline 3 & Merek AXIS menarik & 0,423 & 0,3 & Valid \\
\hline 4 & Merek AXIS mempunyai banyak manfaat & 0,498 & 0,3 & Valid \\
\hline 5 & Merek AXIS berbeda dengan produk sejenis & 0,506 & 0,3 & Valid \\
\hline 6 & Merek AXIS berkualitas & 0,026 & 0,3 & Tidak Valid \\
\hline 7 & Kemasan AXIS menarik & 0,546 & 0,3 & Valid \\
\hline 8 & Daya tahan kemasan AXIS lebih lama & 0,578 & 0,3 & Valid \\
\hline 9 & Kemasan AXIS mudah penyimpanannya & 0,635 & 0,3 & Valid \\
\hline 10 & Kemasan AXIS mudah dipegang & 0,593 & 0,3 & Valid \\
\hline 11 & Ukuran kemasan AXIS fleksibel & 0,074 & 0,3 & Tidak Valid \\
\hline 12 & Desain kemasan AXIS lebih menarik & 0,599 & 0,3 & Valid \\
\hline 13 & Jaringan AXIS selalu bagus dan tidak putus-putus & 0,038 & 0,3 & Tidak Valid \\
\hline 14 & AXIS memberikan telpon gratis & 0,592 & 0,3 & Valid \\
\hline 15 & AXIS memberikan sms gratis & 0,561 & 0,3 & Valid \\
\hline 16 & Cepat dalam mengatasi bila ada jaringan bermasalah & 0,477 & 0,3 & Valid \\
\hline 17 & AXIS memberikan kemudahan dalam internet & 0,628 & 0,3 & Valid \\
\hline 18 & AXIS memberikan kemudahan untuk pengguna BlackBerry & $-0,256$ & 0,3 & Tidak Valid \\
\hline
\end{tabular}

Sumber : data primer diolah 2013

Tabel 5 menunjukkan bahwa dari 18 item pernyataan pada variabel produk, 13 item adalah valid karena nilai (corrected item total correlation) lebih besar dibanding 0,30. Sedangkan 5 item sisanya adalah tidak valid karena nilai (corrected item total 
correlation) lebih kecil dibanding 0,30 seperti yang dijelaskan oleh Sugiono dan Wibowo (2004).

Tabel 6.

Hasil Uji Validitas Harga

\begin{tabular}{|c|l|c|c|c|}
\hline No. & \multicolumn{1}{|c|}{ Pernyataan } & $\begin{array}{c}\text { R } \\
\text { Hitung }\end{array}$ & $\begin{array}{c}\text { R } \\
\text { Tabel }\end{array}$ & $\begin{array}{c}\text { Keteranga } \\
\mathbf{n}\end{array}$ \\
\hline 1 & Harga kartu perdana AXIS terjangkau oleh konsumen & 0,623 & 0,3 & Valid \\
\hline 2 & Harga isi ulang AXIS terjangkau oleh konsumen & 0,422 & 0,3 & Valid \\
\hline 3 & Harga AXIS sesuai dengan fitur yang ditawarkan & 0,476 & 0,3 & Valid \\
\hline 4 & Harga AXIS untuk BBM sangat menggiurkan & 0,521 & 0,3 & Valid \\
\hline 5 & Harga AXIS sebanding dengan kualitasnya & 0,521 & 0,3 & Valid \\
\hline 6 & $\begin{array}{l}\text { Harga AXIS lebih competitor dibandingkan dengan } \\
\text { pesaingnya }\end{array}$ & 0,524 & 0,3 & Valid \\
\hline
\end{tabular}

Sumber : Data Primer diolah 2013

Berdasarkan tabel 6, terlihat bahwa ke enam item pernyataan pada variabel harga, seluruhnya adalah valid karena nilai (corrected item total correlation) lebih besar dibanding 0,30 seperti yang dijelaskan oleh Sugiono dan Wibowo (2004).

Tabel 7.

Hasil Uji Validitas Promosi

\begin{tabular}{|c|c|c|c|c|}
\hline No. & Pernyataan & R Hitung & $\begin{array}{c}\mathbf{R} \\
\text { Tabel } \\
\end{array}$ & Keterangan \\
\hline 1 & Pesan iklan AXIS di Televisi mudah dimengerti & 0,641 & 0,3 & Valid \\
\hline 2 & $\begin{array}{l}\text { Pesan iklan AXIS di Televisi memberikan informasi yang } \\
\text { jelas }\end{array}$ & 0,448 & 0,3 & Valid \\
\hline 3 & Pesan iklan AXIS di Televisi menarik untuk ditonton & $-0,054$ & 0,3 & Tidak Valid \\
\hline 4 & $\begin{array}{l}\text { Pesan iklan AXIS di Televisi memperhatikan dari segi } \\
\text { etika }\end{array}$ & 0,709 & 0,3 & Valid \\
\hline 5 & $\begin{array}{l}\text { Pesan iklan AXIS di Televisi mudah dipahami oleh } \\
\text { berbagai usia }\end{array}$ & 0,548 & 0,3 & Valid \\
\hline 6 & Pesan iklan AXIS di Televisi mudah diingat & 0,526 & 0,3 & Valid \\
\hline 7 & Fitur dan gambar iklan AXIS kreatif dan inovatif & 0,015 & 0,3 & Tidak Valid \\
\hline 8 & Pilihan warna iklan AXIS menarik dan berkarakter & 0,675 & 0,3 & Valid \\
\hline 9 & $\begin{array}{l}\text { Durasi iklan AXIS yang singkat dan padat dengan tidak } \\
\text { berbelit-belit }\end{array}$ & 0,540 & 0,3 & Valid \\
\hline 10 & $\begin{array}{l}\text { Penggunaan kata atau narasi ikl;an AXIS luwes dan } \\
\text { mudah dipahami }\end{array}$ & 0,670 & 0,3 & Valid \\
\hline 11 & $\begin{array}{l}\text { Desain iklan AXIS sesuai dengan pesan iklan yang } \\
\text { disampaikan }\end{array}$ & 0,176 & 0,3 & Tidak Valid \\
\hline 12 & $\begin{array}{l}\text { Iklan AXIS memiliki warna dan tampilan iklan yang } \\
\text { menarik }\end{array}$ & 0,719 & 0,3 & Valid \\
\hline 13 & Iklan AXIS di Televisi sangat cocok & 0,485 & 0,3 & Valid \\
\hline 14 & Iklan AXIS di Surat Kabar berdesain menarik & 0,665 & 0,3 & Valid \\
\hline 15 & Iklan AXIS di Radio dapat menjangkau masyarakat & 0,657 & 0,3 & Valid \\
\hline 16 & $\begin{array}{l}\text { Iklan AXIS di Tabloid hadir dengan tampilan yang } \\
\text { mewah }\end{array}$ & 0,074 & 0,3 & Tidak Valid \\
\hline 17 & Iklan AXIS dengan brosur-brosur sangat menarik & 0,512 & 0,3 & Valid \\
\hline 18 & $\begin{array}{l}\text { Iklan AXIS di internet melalui akun facebook dan twitter } \\
\text { lebih berteknologi }\end{array}$ & 0,385 & 0,3 & Valid \\
\hline
\end{tabular}

Sumber : data primer diolah 2013

Berdasarkan tabel 7, dapat dilihat bahwa dari 18 item pernyataan pada variabel promosi, 14 item adalah valid karena nilai (corrected item total correlation) lebih besar dibanding 0,30. Sedangkan 4 item sisanya adalah tidak valid karena nilai (corrected item total correlation) lebih kecil dibanding 0,30 seperti yang dijelaskan oleh Sugiono dan Wibowo (2004). 
Tabel 8.

Hasil Uji Validitas Distribusi

\begin{tabular}{|c|l|c|c|c|}
\hline No. & \multicolumn{1}{|c|}{ Pernyataan } & R Hitung & R Tabel & Keterangan \\
\hline 1 & Tersedia atau mudah didapat & 0,661 & 0,3 & Valid \\
\hline 2 & Tersedia sesuai kebutuhan & 0,680 & 0,3 & Valid \\
\hline 3 & Tersedia sampai ke daerah pelosok & 0,594 & 0,3 & Valid \\
\hline 4 & Persediaan AXIS selalu ada di Outlet & 0,638 & 0,3 & Valid \\
\hline 5 & Persediaan barang pada pengecer terjamin & 0,627 & 0,3 & Valid \\
\hline 6 & Tersedia dalam banyak pilihan & 0,554 & 0,3 & Valid \\
\hline
\end{tabular}

Sumber : Data Primer diolah 2013

Berdasarkan tabel 8, dapat dilihat bahwa ke enam item pernyataan pada variabel distribusi, seluruhnya adalah valid karena nilai (corrected item total correlation) lebih besar dibanding 0,30 seperti yang dijelaskan oleh Sugiono dan Wibowo (2004).

Tabel 9.

Hasil Uji Validitas Keputusan Pembelian Ulang

\begin{tabular}{|c|l|c|c|c|}
\hline No. & \multicolumn{1}{|c|}{ Pernyataan } & $\begin{array}{c}|c| \\
\text { Hitung }\end{array}$ & R Tabel & Keterangan \\
\hline 1 & $\begin{array}{l}\text { Saya akan membeli AXIS kembali karena produknya } \\
\text { berkualitas }\end{array}$ & 0,481 & 0,3 & Valid \\
\hline 2 & $\begin{array}{l}\text { Saya akan membeli AXIS kembali karena mutu dari } \\
\text { produknya tidak diragukan lagi }\end{array}$ & 0,479 & 0,3 & Valid \\
\hline 3 & $\begin{array}{l}\text { Saya akan membeli AXIS kembali karena iklannya yang } \\
\text { menarik }\end{array}$ & 0,592 & 0,3 & Valid \\
\hline 4 & $\begin{array}{l}\text { Saya akan membeli AXIS kembali karena isi ulang yang } \\
\text { mudah }\end{array}$ & 0,570 & 0,3 & Valid \\
\hline 5 & $\begin{array}{l}\text { Saya akan membeli AXIS kembali karena mudah untuk } \\
\text { pengguna BlackBerry seperti saya }\end{array}$ & 0,505 & 0,3 & Valid \\
\hline 6 & $\begin{array}{l}\text { Saya akan membeli AXIS kembali karena banyak telpon } \\
\text { gratis }\end{array}$ & 0,625 & 0,3 & Valid \\
\hline 7 & $\begin{array}{l}\text { Saya akan membeli AXIS kembali karena banyak sms } \\
\text { gratis }\end{array}$ & 0,552 & 0,3 & Valid \\
\hline 8 & $\begin{array}{l}\text { Saya akan membeli AXIS kembali karena harganya sangat } \\
\text { terjangkau }\end{array}$ & 0,567 & 0,3 & Valid \\
\hline 9 & $\begin{array}{l}\text { Saya akan membeli AXIS kembali karena sangat membantu } \\
\text { saya dalam penggunaan internet }\end{array}$ & 0,358 & 0,3 & Valid \\
\hline 10 & $\begin{array}{l}\text { Saya akan membeli AXIS kembali karena mudah didapat / } \\
\text { diperoleh }\end{array}$ & 0,618 & 0,3 & Valid \\
\hline
\end{tabular}

Sumber : Data Primer diolah 2013

Berdasarkan tabel di atas, dapat dilihat bahwa ke sepuluh item pernyataan pada variabel keputusan pembelian ulang, seluruhnya adalah valid karena nilai (corrected item total correlation) lebih besar dibanding 0,30 seperti yang dijelaskan oleh Sugiono dan Wibowo (2004).

\section{Uji Reliabilitas}

Pengujian reliabilitas instrumen dalam suatu penelitian dilakukan karena uji reabilitas bertujuan untuk menge tahui apakah alat pengumpul data poada dasarnya menunjukkan tingkat kemampuan, ketetapan, keakuratan, kestabilan atau konsistensi alat tersebut dalam mengungkapkan gejala-gejala tertentu dari sekelompok individu walaupun dilakukan pada waktu yang berbeda. Uji reliabilitas dilakukan terhadap pertanyaan yang valid. Rumus yang dipakai untuk menguji reabilitas dalam penelitian ini adalah Cronbach's alpha yang penyelesaiannya dilakukan dengan program SPSS 16.0. dalam penentuan tingkat reabilitas suatu instrumen penelitian dapat diterima bila dalam kisaran $\mathrm{r}$ alpha $>0,60 \mathrm{~s} / \mathrm{d}$ 0,80 dianggap baik/rel;iabel serta dalam kisaran $>0,80$ s/d 1.00 dianggap sangat baik/sangat reliabel (santoso, 2001:227) 
Untuk menentukan reliabilitas terhadap butir-butir pernyataan variabel dilaku kan pengujian dengan komputer program SPSS dengan rumus cronbach's alpha. Uji reliabilitas juga dilakukan terhadap 100 orang konsumen. Berdasarkan tingkat relia bilitas, hasil uji koefisien reabilitas ( $\mathrm{r}$ alpha) terhadap kelima variabel yang diuji dapat dirangkum pada tabel dibawah ini.

Tabel 10.

Hasil Uji Reliabilitas

\begin{tabular}{|c|l|c|c|c|}
\hline No. & \multicolumn{1}{|c|}{ Variabel } & $\begin{array}{c}\text { Jumlah } \\
\text { Item }\end{array}$ & $\begin{array}{c}\text { Cronbach's } \\
\text { Alpha }\end{array}$ & Keterangan \\
\hline 1 & Produk & 13 & 0,870 & Reliabel \\
\hline 2 & Harga & 6 & 0,767 & Reliabel \\
\hline 3 & Promosi & 14 & 0,895 & Reliabel \\
\hline 4 & Distribusi & 6 & 0,844 & Reliabel \\
\hline 5 & Keputusan Pembelian Ulang & 10 & 0,822 & Reliabel \\
\hline
\end{tabular}

Sumber : Data Primer diolah 2013

Berdasarkan tabel rangkuman hasil reliabilitas, nilai cronbach's alpha untuk variabel produk, harga, promosi dan distribusi masing-masing sebesar $0.870,0.767$, 0.895, dan 0.844. sedangkan untuk keputusan pembelian ulang sebesar 0,822. hal ini berarti bahwa pernyataan untuk seluruh item pertanyaan adalah sangat baik. Variabel produk, harga, promosi dan distribusi adalah baik untuk keputusan pembelian ulang seperti yang dikemukakan oleh (Santoso, 2001).

Tabel 11.

Persepsi responden mengenai produk AXIS

\begin{tabular}{|c|c|c|c|c|c|c|c|}
\hline \multirow{2}{*}{ No. } & \multirow{2}{*}{ Pernyataan } & \multicolumn{5}{|c|}{ Skor Jawaban Responden } & \multirow{2}{*}{ Rata - rata } \\
\hline & & SS & $\mathbf{S}$ & CS & TS & STS & \\
\hline 1 & Merek AXIS mudah diingat & 10 & 61 & 26 & 3 & & 3.78 \\
\hline 3 & Merek AXIS menarik & 18 & 60 & 20 & 2 & & 3.94 \\
\hline 4 & Merek AXIS mempunyai banyak manfaat & 14 & 60 & 24 & 2 & & 3.86 \\
\hline 5 & Merek AXIS berbeda dengan produk sejenis & 18 & 54 & 28 & & & 3.90 \\
\hline 7 & Kemasan AXIS menarik & 24 & 53 & 17 & 6 & & 3.95 \\
\hline 8 & Daya tahan kemasan AXIS lebih lama & 18 & 57 & 20 & 1 & 4 & 3.84 \\
\hline 9 & Kemasan AXIS mudah penyimpanannya & 23 & 56 & 20 & 1 & & 4.01 \\
\hline 10 & Kemasan AXIS mudah dipegang & 12 & 64 & 21 & 3 & & 3.85 \\
\hline 12 & Desain kemasan AXIS lebih menarik & 15 & 52 & 28 & 5 & & 3.77 \\
\hline 14 & AXIS memberikan telpon gratis & 20 & 54 & 23 & 1 & 2 & 3.89 \\
\hline 15 & AXIS memberikan sms gratis & 23 & 51 & 23 & 2 & 1 & 3.93 \\
\hline 16 & $\begin{array}{l}\begin{array}{l}\text { Cepat dalam mengatasi bila } \\
\text { bermasalah }\end{array} \\
\text { lata jaringan } \\
\end{array}$ & 36 & 49 & 7 & 1 & 7 & 4.06 \\
\hline 17 & AXIS memberikan kemudahan dalam internet & 27 & 41 & 29 & 3 & & 3.92 \\
\hline \multicolumn{7}{|c|}{ Rata-rata } & 3.95 \\
\hline
\end{tabular}

Sumber : Data Primer diolah 2013

Dari tabel 11 rata-rata persepsi responden mengenai produk AXIS adalah sebesar 3.95 atau 79\%. Hal ini menunjukkan bahwa sebagian besar responden menilai merek yang digunakan produk AXIS sudah cukup efektif untuk memposisioningkannya dipikiran masyarakat. Disamping itu sebagian besar responden juga menilai produk AXIS memiliki kualitas yang bagus dan mempunyai mutu sehingga dapat digunakan oleh semua kalangan.

Dari tabel tersebut dapat dijelaskan bahwa rata-rata respon tertinggi dari responden adalah sebesar 4,06. hal ini menunjukkan bahwa merek yang digunakan AXIS sudah sangat melekat dipikiran masyarakat. Dimana untuk pernyataan ini 49 orang responden (49\%) menyatakan setuju. Pernyataan ini juga didukung oleh 36 orang responden $(36 \%)$ menyatakan sangat setuju dan 7 orang responden yang menyatakan 
cukup setuju. Meskipun masih terdapat $1 \%$ responden yang menyatakan tidak setuju dan $7 \%$ responden yang menyatakan sangat tidak setuju dengan pernyataan tersebut, jumlahnya sangat kecil sehingga tidak terlalu mempengaruhi persepsi konsumen untuk tetap membeli produk AXIS tersebut.

Sedangkan rata-rata responden terendah dari konsumen adalah sebesar 3.77. hal ini menunjukkan bahwa sebagian besar responden memiliki persepsi positif terhadap kualitas AXIS. Namun masih terdapat 5\% responden yang menyatakan tidak setuju dengan kualitas yang dimiliki AXIS.

\section{Harga}

Persepsi responden mengenai harga AXIS dapat dilihat pada tabel berikut ini:

Tabel 12.

Persepsi responden mengenai harga AXIS

\begin{tabular}{|c|c|c|c|c|c|c|c|}
\hline \multirow{2}{*}{ No. } & \multirow{2}{*}{ Pernyataan } & \multicolumn{5}{|c|}{ Skor Jawaban Responden } & \multirow{2}{*}{ Rata - rata } \\
\hline & & SS & $\mathbf{S}$ & CS & TS & STS & \\
\hline 1 & $\begin{array}{l}\text { Harga kartu perdana AXIS terjangkau oleh } \\
\text { konsumen }\end{array}$ & 28 & 55 & 15 & 2 & & 4.09 \\
\hline 2 & $\begin{array}{l}\text { Harga isi ulang AXIS terjangkau oleh } \\
\text { konsumen }\end{array}$ & 36 & 43 & 19 & 2 & & 4.13 \\
\hline 3 & $\begin{array}{l}\text { Harga AXIS sesuai dengan fitur yang } \\
\text { ditawarkan }\end{array}$ & 37 & 40 & 16 & 7 & & 4.07 \\
\hline 4 & $\begin{array}{l}\text { Harga AXIS untuk } \\
\text { menggiurkan }\end{array}$ & 35 & 43 & 17 & 5 & & 4.08 \\
\hline 5 & Harga AXIS sebanding dengan kualitasnya & 37 & 43 & 18 & 2 & & 4.15 \\
\hline 6 & $\begin{array}{l}\text { Harga AXIS lebih competitor } \\
\text { dibandingkan dengan pesaingnya }\end{array}$ & 20 & 53 & 25 & 2 & & 3.91 \\
\hline & Rata-rata & & & & & & 4.07 \\
\hline
\end{tabular}

Sumber : Data Primer diolah 2013

Dari tabel 12 rata-rata persepsi responden mengenai harga AXIS adalah sebesar 4.07 atau $81.4 \%$. Hal ini menunjukkan bahwa sebagian besar responden menilai harga AXIS sudah sesuai dengan harapan konsumen dimana harganya stabil sehingga konsumen tetap memilih produk tersebut. Dari tabel tersebut diatas dapat dijelaskan bahwa rata-rata respon tertinggi dari responden adalah sebesar 4.15. Hal ini menunjukkan bahwa sebagian besar responden memilik respon positif terhadap harga AXIS yang telah ditetapkan. Dimana untuk pernyataan ini 43 orang responden (43\%) menyatakan setuju. Pernyataan ini juga didukung oleh 37 orang responden (37\%) menyatakan sangat setuju dan 18 orang responden (18\%) yang menyatakan cukup setuju.

Meskipun masih terdapat 2 responden (2\%) yang menyatakan tidak setuju dengan pernyataan tersebut, jumlahnya sangat kecil sehingga tidak terlalu mempengaruhi persepsi konsumen untuk tetap membeli produk AXIS tersebut.

Sedangkan rata-rata responden terendah dari konsumen adalah sebesar 3.91. hal ini menunjukkan bahwa seba gian besar responden memiliki persepsi positif terhadap kualitas AXIS. Namun masih terdapat $2 \%$ responden yang menyatakan tidak setuju mengenai harga yang ditetapkan AXIS

\section{Promosi}

Persepsi responden mengenai promosi AXIS dapat dilihat pada tabel berikut ini: 
Tabel 13.

Persepsi responden mengenai promosi AXIS

\begin{tabular}{|c|c|c|c|c|c|c|c|}
\hline \multirow{2}{*}{ No. } & \multirow{2}{*}{ Pernyataan } & \multicolumn{5}{|c|}{ Skor Jawaban Responden } & \multirow{2}{*}{ Rata - rata } \\
\hline & & SS & $\mathbf{S}$ & CS & TS & STS & \\
\hline 1 & Pesan iklan AXIS di Televisi mudah dimengerti & 29 & 61 & 7 & 3 & & 4.16 \\
\hline 2 & $\begin{array}{l}\text { Pesan iklan AXIS di Televisi memberikan } \\
\text { informasi yang jelas }\end{array}$ & 43 & 43 & 13 & 1 & & 4.28 \\
\hline 4 & $\begin{array}{l}\text { Pesan iklan AXIS di Televisi memperhatikan dari } \\
\text { segi etika }\end{array}$ & 36 & 53 & 9 & 2 & & 4.23 \\
\hline 5 & $\begin{array}{l}\text { Pesan iklan AXIS di Televisi mudah dipahami oleh } \\
\text { berbagai usia }\end{array}$ & 46 & 44 & 10 & & & 4.36 \\
\hline 6 & Pesan iklan AXIS di Televisi mudah diingat & 59 & 28 & 10 & 3 & & 4.43 \\
\hline 8 & Pilihan warna iklan AXIS menarik dan berkarakter & 42 & 40 & 13 & 1 & 4 & 4.15 \\
\hline 9 & $\begin{array}{l}\text { Durasi iklan AXIS yang singkat dan padat dengan } \\
\text { tidak berbelit-belit }\end{array}$ & 47 & 39 & 13 & 1 & & 4.32 \\
\hline 10 & $\begin{array}{l}\text { Penggunaan kata atau narasi iklan AXIS luwes dan } \\
\text { mudah dipahami }\end{array}$ & 34 & 44 & 19 & 3 & & 4.09 \\
\hline 12 & $\begin{array}{l}\text { Iklan AXIS memiliki warna dan tampilan iklan } \\
\text { yang menarik }\end{array}$ & 40 & 36 & 19 & 5 & & 4.11 \\
\hline 13 & Iklan AXIS di Televisi sangat cocok & 35 & 45 & 15 & 1 & 4 & 4.06 \\
\hline 14 & Iklan AXIS di Surat Kabar berdesain menarik & 32 & 46 & 19 & 1 & 2 & 4.05 \\
\hline 15 & $\begin{array}{l}\begin{array}{l}\text { Iklan AXIS di Radio dapat } \\
\text { masyarakat }\end{array} \\
\end{array}$ & 33 & 51 & 12 & 3 & 1 & 4.12 \\
\hline 17 & Iklan AXIS dengan brosur-brosur sangat menarik & 40 & 45 & 12 & 3 & & 4.22 \\
\hline 18 & $\begin{array}{l}\text { Iklan AXIS di internet melalui akun facebook dan } \\
\text { twitter lebih berteknologi }\end{array}$ & 63 & 24 & 8 & 5 & & 4.45 \\
\hline \multicolumn{7}{|c|}{ Rata-rata } & 4.21 \\
\hline
\end{tabular}

Sumber : Data Primer diolah 2013

Dari tabel 13 rata-rata persepsi responden mengenai promosi AXIS adalah sebesar 21 atau $84.2 \%$ Hal ini menunjukkan bahwa sebagian besar responden menilai iklan AXIS baik di televisi maupun media cetak sangat baik. Begitu halnya personal selling yang dilakukan AXIS dalam mempro mosikan produknya dapat menarik konsumen untuk membeli produk tersebut.

Dari tabel tersebut diatas dapat dijelaskan bahwa rata-rata respon tertinggi dari responden adalah sebesar 4.45. Hal ini menunjukkan bahwa sebagian besar responden memilik respon positif terhadap iklan AXIS di televisi dan media cetak. Dimana untuk pernyataan ini 24 orang responden (24\%) menyatakan setuju. Pernyataan ini juga didukung oleh 63 orang responden (63\%) menyatakan sangat setuju dan 8 orang responden $(8 \%)$ yang menyatakan cukup setuju. Meskipun masih terdapat 5 responden $(5 \%)$ yang menyatakan tidak setuju dengan pernyataan tersebut, jumlahnya sangat kecil sehingga tidak terlalu mempengaruhi persepsi konsumen untuk tetap membeli produk AXIS tersebut.

Sedangkan rata-rata responden terendah dari konsumen adalah sebesar 4.05. hal ini menunjukkan bahwa sebagian besar responden memiliki persepsi positif terhadap iklan AXIS di media cetak dan televisi. Namun masih terdapat 2\% responden yang menyatakan sangat tidak setuju dan $1 \%$ yang menyatakan tidak setuju bahwa iklan AXIS di media cetak dan televisi menarik. Namun jumlah responden yang menyatakan tidak setuju relative sangat kecil sehingga hal tersebut tidak terlalu mempengaruhi persepsi responden mengenai produk AXIS sehingga konsumen masih tetap memilih produk AXIS. 


\section{Distribusi}

Persepsi responden mengenai distribusi AXIS dapat dilihat pada tabel berikut ini :

Tabel 14.

Persepsi responden mengenai distribusi AXIS

\begin{tabular}{|c|c|c|c|c|c|c|c|}
\hline \multirow{2}{*}{ No. } & \multirow{2}{*}{ Pernyataan } & \multicolumn{5}{|c|}{ Skor Jawaban Responden } & \multirow{2}{*}{ Rata - rata } \\
\hline & & SS & $\mathbf{S}$ & $\mathrm{CS}$ & TS & STS & \\
\hline 1 & Tersedia atau mudah didapat & 32 & 48 & 18 & 2 & & 4.10 \\
\hline 2 & Tersedia sesuai kebutuhan & 22 & 52 & 25 & 1 & & 3.95 \\
\hline 3 & Tersedia sampai ke daerah pelosok & 30 & 47 & 18 & 5 & & 4.02 \\
\hline 4 & Persediaan AXIS selalu ada di Outlet & 31 & 49 & 16 & 4 & & 4.07 \\
\hline 5 & Persediaan barang pada pengecer terjamin & 20 & 54 & 25 & 1 & & 3.93 \\
\hline 6 & Tersedia dalam banyak pilihan & 25 & 54 & 21 & & & 4.04 \\
\hline
\end{tabular}

Sumber : Data Primer diolah 2013

Dari tabel 14 rata-rata persepsi responden mengenai distribusi AXIS adalah sebesar 4.01 atau $80.2 \%$ Hal ini menunjukkan bahwa sebagian besar responden menilai pengadaan AXIS di outlet-outlet, counter-counter, toko-toko, supermarket dan swalayan sudah $\mathrm{b}$ aik, begitu pula halnya dengan sistem distribusi yang diterapkan sehingga penyebaran AXIS di outlet-outlet, counter-counter, toko-toko, supermarket dan swalayan merata sehingga apabila dibutuhkan konsumen lebih mudah memperolehnya.

Dari tabel tersebut di atas dapat dijelaskan bahwa rata-rata respon tertinggi dari responden adalah sebesar 10. Hal ini menunjukkan bahwa sebagian besar responden memilik respon positif terhadap pengadaan AXIS di outlet-outlet, counter-counter, toko-toko, supermarket dan swalayan. Dimana untuk pernyataan ini 48 orang responden $(48 \%)$ menyatakan setuju. Pernyataan ini juga didukung oleh 32 orang responden $(32 \%)$ menyatakan sangat setuju dan 18 orang responden (18\%) yang menyatakan cukup setuju. Meskipun masih terdapat 2 responden (2\%) yang menyatakan tidak setuju dengan pernyataan tersebut, jumlahnya sangat kecil sehingga tidak terlalu mempengaruhi persepsi konsumen untuk tetap membeli produk AXIS tersebut.

Sedangkan rata-rata responden terendah dari konsumen adalah sebesar 3.93. hal ini menunjukkan bahwa sebagian besar responden memiliki persepsi positif terhadap pemerataan distribusi AXIS. Namun masih terdapat 1\% responden yang menyatakan tidak setuju bahwa distribusi AXIS masih belum merata sehingga masih mengalami kesulitan memperolehnya. Namun jumlah responden yang menyatakan tidak setuju relative sangat kecil sehingga hal tersebut tidak terlalu mempengaruhi persepsi responden mengenai produk AXIS sehingga konsumen masih tetap memilih produk AXIS.

\section{Keputusan Pembelian Ulang}

Persepsi responden mengenai keputusan pembelian ulang AXIS dapat dilihat pada tabel berikut ini: 
Tabel 15.

Persepsi responden mengenai keputusan pembelian ulang AXIS

\begin{tabular}{|c|c|c|c|c|c|c|c|}
\hline \multirow{2}{*}{ No. } & \multirow{2}{*}{ Pernyataan } & \multicolumn{5}{|c|}{ Skor Jawaban Responden } & \multirow{2}{*}{$\begin{array}{c}\text { Rata - } \\
\text { rata }\end{array}$} \\
\hline & & SL & SR & KK & JR & $\mathbf{T P}$ & \\
\hline 1 & $\begin{array}{l}\text { Saya akan membeli AXIS kembali karena } \\
\text { produknya berkualitas }\end{array}$ & 22 & 60 & 16 & 1 & 1 & 4.01 \\
\hline 2 & $\begin{array}{l}\text { Saya akan membeli AXIS kembali karena mutu } \\
\text { dari produknya tidak diragukan lagi }\end{array}$ & 27 & 52 & 18 & 3 & & 4.03 \\
\hline 3 & $\begin{array}{l}\text { Saya akan membeli AXIS kembali karena iklannya } \\
\text { yang menarik }\end{array}$ & 41 & 34 & 23 & 2 & & 4.14 \\
\hline 4 & $\begin{array}{l}\text { Saya akan membeli AXIS kembali karena isi ulang } \\
\text { yang mudah }\end{array}$ & 36 & 45 & 18 & 1 & & 4.15 \\
\hline 5 & $\begin{array}{l}\text { Saya akan membeli AXIS kembali karena mudah } \\
\text { untuk pengguna BlackBerry seperti saya }\end{array}$ & 29 & 50 & 18 & 2 & 1 & 4.04 \\
\hline 6 & $\begin{array}{l}\text { Saya akan membeli AXIS kembali karena banyak } \\
\text { telpon gratis }\end{array}$ & 37 & 43 & 18 & 1 & 1 & 4.14 \\
\hline 7 & $\begin{array}{l}\text { Saya akan membeli AXIS kembali karena banyak } \\
\text { sms gratis }\end{array}$ & 39 & 52 & 9 & & & 4.30 \\
\hline 8 & $\begin{array}{l}\text { Saya akan membeli AXIS kembali karena harganya } \\
\text { sangat terjangkau }\end{array}$ & 23 & 51 & 24 & 1 & 1 & 3.94 \\
\hline 9 & $\begin{array}{l}\text { Saya akan membeli AXIS kembali karena sangat } \\
\text { membantu saya dalam penggunaan internet }\end{array}$ & 47 & 49 & 2 & 2 & & 4.39 \\
\hline 10 & $\begin{array}{l}\text { Saya akan membeli AXIS kembali karena mudah } \\
\text { didapat / diperoleh }\end{array}$ & 42 & 47 & 11 & & & 4.31 \\
\hline & Rata-rata & & & & & & 4.14 \\
\hline
\end{tabular}

Sumber : Data Primer diolah 2013

Dari tabel 15 rata-rata persepsi responden mengenai keputusan pembelian ulang AXIS adalah sebesar 14 atau $82.8 \%$ Hal ini menunjukkan bahwa sebagian besar responden memiliki keinginan membeli ulang yang tinggi terhadap produk AXIS karena kualitas dan mutu produk tersebut tidak diragukan lagi. Begitu juga halnya sebagian besar responden tertarik membeli produk tersebut karena harganya yang terjangkau. Disamping dengan seringnya iklan produk tersebut ditampilkan di televisi dan media cetak dapat menarik perhatian konsumen untuk membelinya. Dan dengan adanya distribusi produk yang merata di seluruh outlet-outlet, counter-counter, toko-toko, supermarket dan swalayan akan memudahkan konsumen untuk memperoleh produk tersebut.

Dari tabel tersebut diatas dapat dijelaskan bahwa rata-rata respon tertinggi dari responden adalah sebesar 4.39. Hal ini menunjukkan bahwa sebagian besar responden memiliki keinginan membeli ulang yang tinggi terhadap produk AXIS karena kualitas dan mutu produk tersebut tidak diragukan lagi, harga yang terjangkau, promosi dengan iklan yang menarik serta pemerataan dalam distribusinya. Dimana untuk pernyataan ini 49 orang responden (49\%) menyatakan sering. Pernyataan ini juga didukung oleh 47 orang responden (47\%) menyatakan selalu dan 2 orang responden (2\%) yang menyatakan kadang-kadang. Meskipun masih terdapat 2 responden (2\%) yang menyatakan tidak pernah dengan pernyataan tersebut, jumlahnya sangat kecil sehingga tidak terlalu mempengaruhi persepsi konsumen untuk tetap membeli produk AXIS tersebut.

Sedangkan rata-rata responden terendah dari konsumen adalah sebesar 3.94. hal ini menunjukkan bahwa sebagian besar responden memiliki persepsi positif tentang keinginan membeli ulang AXIS. Namun masih terdapat $1 \%$ responden yang menyatakan tidak pernah dan $1 \%$ yang menyatakan jarang untuk membeli ulang AXIS kembali. Namun jumlah responden yang menyatakan tidak setuju relative sangat kecil 
sehingga hal tersebut tidak terlalu mempengaruhi persepsi responden mengenai produk AXIS sehingga konsumen masih tetap memilih produk AXIS.

\section{Analisa Regresi Berganda}

Untuk melihat pengaruh variabel produk (X1), variabel harga (X2), variabel promosi (X3), dan variabel distribusi (X4) terhadap keputusan pembelian ulang maka digunakan analisa regresi berganda berdasarkan hasil penjelasan data dengan bantuan program SPSS dapat dilihat analisis yang terlampir pada halaman skripsi ini.

Hasil analisa regresi dapat dilihat pada tabel berikut:

Tabel 16.

\section{Hasil Analisa Regresi}

\begin{tabular}{|c|c|c|c|c|c|c|c|c|}
\hline \multicolumn{9}{|c|}{ Coefficients } \\
\hline \multirow{2}{*}{\multicolumn{2}{|c|}{ Model }} & \multicolumn{2}{|c|}{$\begin{array}{c}\text { Unstandardized } \\
\text { Coeff icients }\end{array}$} & \multirow{2}{*}{$\begin{array}{l}\text { Standardized } \\
\text { Coeff icients } \\
\text { Beta }\end{array}$} & \multirow[b]{2}{*}{$t$} & \multirow[b]{2}{*}{ Sig. } & \multicolumn{2}{|c|}{ Collinearity Statistics } \\
\hline & & B & Std. Error & & & & Tolerance & VIF \\
\hline \multirow[t]{5}{*}{1} & (Constant) & 6,529 & 2,177 & & 3,000 &, 003 & & \\
\hline & Produk (X1) & , 173 & ,081 & ,225 & 2,142 & ,035 & ,250 & 4,007 \\
\hline & Harga (X2) & ,381 & ,153 & ,256 & 2,483 & ,015 & ,258 & 3,869 \\
\hline & Promosi (X3) & , 155 & ,067 & 235 & 2,310 & ,023 & ,266 & 3,759 \\
\hline & Distribusi (X4) & ,321 & ,146 & ,224 & 2,193 & ,031 & ,332 & 3,783 \\
\hline
\end{tabular}

a. Dependent Variable: Keputusan Pembelian Ulang (Y)

Dari data di atas dibuat persamaan regresi berganda sebagai berikut :

$\mathbf{Y}=\mathbf{a}+\mathrm{b} 1 \mathrm{X} 1+\mathrm{b} 2 \mathrm{X} 2+\mathrm{b3X3}+\mathrm{b} 4 \mathrm{X} 4+\mathrm{e}$

$\mathrm{Y}=6.529+0.173+0.381+0.155+0.321+\mathrm{e}$

Dari persamaan tersebut dapat dijelaskan bahwa :

a. Varibel produk mempengaruhi keputusan pembelian ulang AXIS dengan nilai regresi sebesar 0,173 .

b. Variabel harga mempengaruhi keputusan pembelian ulang AXIS dengan nilai regresi sebesar 0,381 .

c. Variabel promosi mempengaruhi keputusan pembelian ulang AXIS dengan nilai regresi sebesar 0,155 .

d. Variabel distribusi mempengaruhi keputusan pembelian ulang AXIS dengan nilai regresi sebesar 0,321 .

Sementara jika tidak ada keempat variabel tersebut maka keputusan pembelian ulang konsumen adalah sebesar konstanta yang dihasilkan yakni sebesar 6,529.

Koefisien regresi yang bertanda positif (+) menandakan arah hubungan yang searah/positif, sedangkan bila koefisien regresi bertanda negative (-) menunjukkan arah hubungan yang terbalik antara variabel Independent $(\mathrm{X})$ dengan variabel dependent $(\mathrm{Y})$. Dimana pada penelitian ini didapatkan hasil koefisien regresi positif (+) untuk variabel produk, harga, promosi, distribusi dan keputusan pembelian ulang. Artinya produk, harga, promosi dan distribusi mempengaruhi keputusan pembelian ulang konsumen dalam membeli AXIS.

\section{Pengujian Hipotesis}

\section{Uji Simultan dengan F-test (Anova)}

Uji F untuk menetukan apakah secara serentak/bersama-sama variabel independent mampu menjelaskan variabel dependent dengan baik atau apakah variabel independent secara bersama-sama mempunyai pengaruh yang signifikan terhadap variabel dependent. Pada tabel anova dapat dilihat pengaruh variabel independent berupa produk, harga, promosi dan distribusi terhadap keputusan pembelian ulang 
AXIS secara simultan/bersama. Dimana setelah dilakukan pengana lisaan dengan SPSS 16.0 hasil dapat dilihat pada tabel sebagai berikut:

Tabel 17.

Hasil Pengujian Hipotesis untuk Uji Simultan dengan F-test

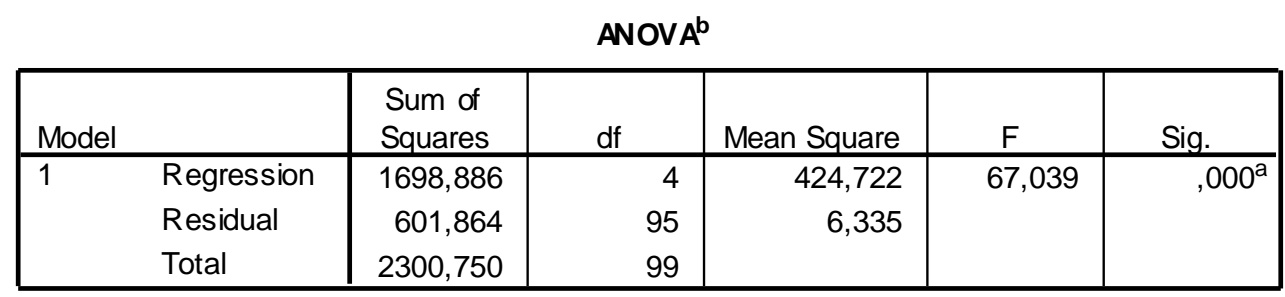

a. Predictors: (Constant), Distribusi (X4), Promosi (X3), Harga (X2), Produk (X1)

b. Dependent Variable: Keputusan Pembelian Ulang $(\mathrm{Y})$

Sumber : data primer diolah 2013

Uji signifikan simultan/bersama-sama (uji statistik fF) menghasilkan nilai $\mathrm{F}$ hitung sebesar 67.039 pada derajat bebas $1(\mathrm{dfl})=$ jumlah variabel $-1=5-1=4$, dan derajat $2(\mathrm{dfl})=\mathrm{n}-\mathrm{k}-1=100-4-1=95$, dimana $\mathrm{n}=$ jumlah sampel, $\mathrm{k}=$ jumlah variabel independent, nilai $\mathrm{f}$ tabel pada taraf kepercayaan signifikansi 0,05 adalah 2.467 dengan demikian $\mathrm{F}$ hitung $=67.039>\mathrm{F}$ tabel $=2.467$ dengan tingkat signifikansi 0,000 . karena probabilitasnya signifikansi jauh lebih kecil dari sig $<0,05$, maka model regresi dapat dipergunakan untuk memprediksi pengaruh produk, harga, promosi dan distribusi terhadap keputusan pembelian ulang AXIS atau dapat dikatakan bahwa produk, harga, promosi dan distribusi berpengaruh dalam memprediksi keputusan pembelian ulang AXIS.

Uji t

Uji statistik $\mathrm{t}$ pada dasarnya digunakan untuk melihat pengaruh variabel independent terhadap variabel dependent secara parsial. Dimana pada peneliian ini untuk melihat pengaruh produk, harga, promosi dan distribusi terhadap keputusan pembelian ulang AXIS secara parsial/individu adalah sebagai berikut:

Tabel 18.

Hasil Pengujian Hipotesis untuk Uji Parsial dengan T - test

\begin{tabular}{|c|l|c|c|c|}
\hline No. & \multicolumn{1}{|c|}{ Variabel } & T Hitung & Sign & Keterangan \\
\hline 1 & Produk & 2.142 &, 035 & Signifikan \\
\hline 2 & Harga & 2.483 &, 015 & Signifikan \\
\hline 3 & Promosi & 2.310 &, 023 & Signifikan \\
\hline 4 & Distribusi & 2.193 &, 031 & Signifikan \\
\hline
\end{tabular}

Sumber : data primer diolah 2013

\section{Pengaruh Produk terhadap Kepu tusan Pembelian Ulang Konsumen}

Dari hasil uji $\mathrm{T}$ statistik yang telah dilakukan, ditemukan nilai t-hitung 2.142 dengan signifikansi $0.035<0.05$ dan t-tabel untuk alpha 0,05 dan $\mathrm{df}=95$ adalah 1.985 dengan demikian t-hitung < t-tabel dengan demikian $\mathrm{H} 1$ diterima artinya produk berpengaruh positif dan signifikan terhadap keputusan pembe lian ulang konsumen pada AXIS. Hal ini menunjukkan semakin baik variabel produk AXIS maka semakin tinggi keputusan pembelian ulang konsumen pada AXIS.

\section{Pengaruh Harga terhadap Keputusan Pembelian Ulang Konsumen}

Dari hasil Uji T statistik yang telah dilakukan, ditemukan nilai t-hitung 2.483 dengan signifikansi $0,015<0,05$ dan t-tabel untuk alpha 0.05 dan $\mathrm{df}=95$ adalah 1.985 demikian t-hitung < t-tabel dengan demikian $\mathrm{H} 2$ diterima artinya harga 
berpengaruh positif dan signifikan terhadap keputusan pembe lian ulang konsumen pada AXIS. Hal ini menunjukkan semakin terjangkau harga produk AXIS maka semakin tinggi keputusan pembelian ulang konsumen pada AXIS.

\section{Pengaruh Promosi terhadap Keputusan Pembelian Ulang Konsumen}

Dari hasil Uji T statistik yang telah dilakukan, ditemukan nilai t-hitung 2.310 dengan signifikansi $0,023<0,05$ dan t-tabel untuk alpha 0.05 dan $\mathrm{df}=95$ adalah 1.985 demikian t-hitung < t-tabel dengan demikian $\mathrm{H} 3$ diterima artinya promosi berpengaruh positif dan signifikan terhadap keputusan pembelian ulang konsumen pada AXIS. Hal ini menunjukkan semakin baik promosi yang dilakukan perusahaan AXIS maka semakin tinggi keputusan pembelian ulang konsumen pada AXIS.

\section{Pengaruh Distribusi terhadap Keputusan Pembelian Ulang Konsumen}

Dari hasil Uji T statistik yang telah dilakukan, ditemukan nilai t-hitung 2.193 dengan signifikansi $0,031<0,05$ dan t-tabel untuk alpha 0.05 dan $\mathrm{df}=95$ adalah 1.985 demikian t-hitung < t-tabel dengan demikian $\mathrm{H} 4$ diterima artinya distribusi berpengaruh positif dan signifikan terhadap keputusan pembelian ulang konsumen pada AXIS. Hal ini menunjukkan semakin baik distribusi yang dilakukan perusahaan AXIS maka semakin tinggi keputusan pembelian ulang konsumen pada AXIS.

\section{Uji Koefisien Determinasi (r2)}

Nugroho (2005), menyatakan untuk regresi linear berganda sebaiknya menggunakan R square yang sudah disesuaikan atau tertulis Adjusted R square untuk melihat koefisien determinasi, karena disesuaikan dengan junlah variabel independent yang digunakan, dimana jika variabel independent 1 (satu) maka menggu nakan $\mathrm{R}$ square dan jika telah malebihi 1 (satu) menggunakan Adjusted R square. Dari hasil pengolahan data (data primer) yang dapat dilihat pada lampiran pada table Model Summary b diperoleh hasil penelitian bahwa Adjusted R square adalah sebesar 72.7\%. Hal ini berarti variabel produk, harga, promosi dan distribusi mempengaruhi keputusan pembelian ulang AXIS di Kota Padang sebesar 72.7\%. Sedangkan sisanya sebesar $27.3 \%$ dijelaskan oleh variabel-variabel lain seperti perilaku kebiasaan, pemasaran dan lainnya yang tidak diteliti dalam penelitian ini.

\section{PEMBAHASAN}

Dari hasil uji hipotesis menunjukkan bahwa variabel produk berpengaruh positif dan memiliki hubungan yang kuat terhadap keputusan pembelian ulang AXIS di kota Padang dengan nilai koeefisien regresi yang bernilai positif yaitu sebesar 0,173 . Hal ini menunjukkan bahwa variabel produk mempunyai pengaruh yang positif yang cukup kuat untuk menimbulkan keputusan pembelian ulang yang berarti konsumen akan mencari informasi mengenai AXIS. Jika konsumen mera sa produk tersebut dapat memberikan kepuasan dalam memenuhi kebu tuhannya maka akan timbul keinginan untuk membeli. Dari hasil uji T pada variabel produk memiliki nilai yang signifikan yaitu 2.142 dan t-tabel untuk alpha 0,05 dan $\mathrm{df}=95$ adalah 1.985 dengan demikian t-hitung > t-tabel, hal ini berarti varibel produk berpengaruh signifikan terhadap keputusan pembelian ulang dengan nilai signifikansinya (sig) sebesar 0,035. Maksudnya variabel produk berpe ngaruh langsung pada keputusan pembelian ulang konsumen.

Dari hasil analisa deskriptif untuk faktor produk diperoleh nilai rata-rata sebesar 3.95 atau $79 \%$. Hal ini menunjukkan bahwa sebagian besar responden menilai merek yang diguna kan produk AXIS sudah cukup efektif untuk memposisioningkannya dipikiran masyarakat. Di samping itu sebagian besar responden juga menilai produk 
AXIS memiliki kualitas yang bagus dan mempunyai mutu sehingga dapat digunakan oleh semua kalangan.

Hasil Uji hipotesis pada variabel kedua yaitu variabel harga menunjukkan bah wa variabel harga berpengaruh positif dan signifikan terhadap keputusan pem belian ulang. Hal ini dapat kita lihat dari nilai regresi berganda yang bernilai positif yaitu sebesar 0,381 dan nilai t hitungnya sebesar 2.483 dan t-tabel untuk alpha 0,05 dan df $=$ 95, adalah 1.985 dengan demikian t0hitung > t-tabel dengan demikian variabel harga berpengaruh signifikan terhadap keputusan pembe lian ulang AXIS.

Dari hasil analisa deskriptif untuk faktor harga diperoleh nilai rata-rata persepsi responden sebesar 4.07 atau $81.4 \%$. Hal ini menunjukkan bahwa sebagian besar responden menilai harga AXIS sudah sesuai dengan harapan konsumen dimana harganya stabil sehingga konsumen tetap memilih produk tersebut.

Hasil uji hipotesis pada variabel ketiga yaitu variabel promosi menunjukkan bahwa variabel promosi berpengaruh positif dan signifikan terhadap keputusan pembelian ulang. Hal ini dapat kita lihat dari nilai regresi berganda yang bernilai positif yaitu sebesar 0,155 dan nilai t hitungnya sebesar 2.310 dan t-tabel untuk alpha 0,05 dan $\mathrm{df}=95$ adalah 1.985 dengan demikian t-hitung $>$ t-tabel dengan demikian variabel promosi berpengaruh signifikan terhadap keputusan pembelian ulang AXIS.

Dari hasil analisa deskriptif untuk faktor promosi diperoleh nilai rata-rata persepsi responden sebesar 4.21 atau $84.2 \%$. Hal ini menunjukkan bahwa sebagian besar responden menilai iklan AXIS baik di televisi maupun media cetak sangat baik. Begitu halnya personal selling yang dilakukan AXIS dalam mempromosikan produknya dapat menarik konsumen untuk membeli produk tersebut.

Hasil uji hipotesis pada variabel keempat yaitu variabel distribusi menunjukkan bahwa variabel distribusi berpengaruh positif dan signifikan terhadap keputusan pembelian ulang konsumen. Hal ini dapat kita lihat dari nilai regresi berganda yang bernilai positif yaitu sebesar 0,321 dan nilai t hitungnya sebesar 2.193 dan t-tabel untuk alpha 0,05 dan $\mathrm{df}=95$ adalah 1.985 dengan demikian t-hitung $>$ t-tabel dengan demikian variabel distribusi berpengaruh signifikan terhadap keputusan pembelian ulang AXIS.

Dari hasil analisa deskriptif untuk faktor distribusi diperoleh nilai rata-rata persepsi responden sebesar 4.01 atau $80.2 \%$. Hal ini menunjukkan bahwa sebagian besar responden menilai pengadaan AXIS di outlet-outlet, counter-counter, toko-toko, supermarket dan swalayan sudah b aik, begitu pula halnya dengan sistem distribusi yang diterapkan sehingga penyebaran AXIS di outlet-outlet, counter-counter, tokotoko, supermarket dan swalayan merata sehingga apabila dibutuhkan konsumen lebih mudah memperolehnya.

Dari hasil Uji signifikan simultan/bersama-sama (uji statistik F) menghasilkan nilai $\mathrm{F}$ hitung sebesar 67.039 pada derajat bebas $1(\mathrm{dfl})=$ jumlah variabel $-1=5-1=$ 4 , dan derajat $2(\mathrm{dfl})=\mathrm{n}-\mathrm{k}-1=100-4-1=95$, dimana $\mathrm{n}=$ jumlah sampel, $\mathrm{k}=$ jumlah variabel independent, nilai $\mathrm{f}$ tabel pada taraf kepercayaan signifikansi 0,05 adalah 2.467 dengan demikian $\mathrm{F}$ hitung $=67.039>\mathrm{F}$ tabel $=2.467$ dengan tingkat signifikansi 0,000. karena probabilitasnya signifikansi jauh lebih kecil dari sig < 0,05, maka model regresi dapat dipergunakan untuk memprediksi pengaruh produk, harga, promosi dan distribusi terhadap keputusan pembelian ulang AXIS atau dapat dikatakan bahwa produk, harga, promosi dan distribusi berpengaruh dalam memprediksi keputusan pembelian ulang AXIS. 
Temuan dalam ini sesuai dengan hasil penelitian yang dilakukan oleh Ferry Irawan (2010:72) tentang pengaruh bauran pemasaran terhadap keputusan pembelian ulang rokok sampoerna avolution pada mahasiswa fakultas ekonomi UNP diperoleh hasil bahwa harga, produk, promosi dan distribusi mempunyai hubungan yang positif dan berpengaruh signifikan terhadap keputusan pembelian ulang rokok sampoerna avolution pada mahasiswa fakultas ekonomi UNP.

Penelitian yang dilakukan oleh lysa Eka Rusvida (2007:61) tentang pengaruh produk, harga dan iklan terhadap keputusan pembelian konsumen dalam membeli ulang Kripik balado Christine Hakim sebagai oleh-oleh dari kota Padang diperoleh hasil bahwa produk, harga dan iklan mempunyai hubungan positif dan berpengaruh signifikan terhadap frekuensi pembelian ulang Kripik balado Christine Hakim sebagai oleh-oleh dari kota Padang.

\section{SIMPULAN}

Berdasarkan hasil pengolahan data dan pembahasan terhadap hasil penelitian yang dilakukan terhadap 100 responden konsumen AXIS di Kota Padang mengenai pengaruh produk, harga, promosi dan distribusi terhadap keputusan pembelian ulang AXIS di Kota Padang, maka dapat diambil kesimpulan sebagai berikut:

1. Dari hasil penelitian diketahui bahwa variabel produk berpengaruh signifikan terhadap keputusan pembelian ulang AXIS di Kota Padang. Pengaruh ini ditunjukkan oleh nilai t-hitung lebih besar dari nilai t-tabel.

2. Dari hasil penelitian diketahui bahwa variabel harga berpengaruh signifikan terhadap keputusan pembelian ulang AXIS di Kota Padang. Pengaruh ini ditunjukkan oleh nilai t-hitung lebih besar dari nilai t-tabel.

3. Dari hasil penelitian diketahui bahwa variabel promosi berpengaruh signifikan terhadap keputusan pembelian ulang AXIS di Kota Padang. Pengaruh ini ditunjukkan oleh nilai t-hitung lebih besar dari nilai t-tabel.

4. Dari hasil penelitian diketahui bahwa variabel distribusi berpengaruh signifikan terhadap keputusan pembelian ulang AXIS di Kota Padang. Pengaruh ini ditunjukkan oleh nilai t-hitung lebih besar dari nilai t-tabel.

Dari hasil Uji Koefisien determinasi diperoleh hasil penelitian bahwa Adjusted R square adalah sebesar $72.7 \%$. Hal ini berarti variabel produk, harga, promosi dan distribusi mempengaruhi keputusan pembelian ulang AXIS di Kota Padang sebesar 72.7\%. Sedangkan sisanya sebesar $27.3 \%$ dijelaskan oleh variabel-variabel lain seperti perilaku kebiasaan, pemasaran dan lainnya yang tidak diteliti dalam penelitian ini.

\section{DAFTAR PUSTAKA}

Andika, A., \& Susanti, F. (2018). Pengaruh Marketing Mix Terhadap Keputusan Pembelian Parfum di Azzwars Parfum Lubeg Padang. https://doi.org/10.31227/osf.io/upgc3

Aziz, N. (2019). Pengaruh Atribut Produk Terhadap Minat Beli Sepeda Motor Honda Dealer Amanah Lubuk Alung. https://doi.org/10.17605/OSF.IO/BNDAE

F., \& Afriyeni, A. (2019). Aktivitas Pemasaran Produk Tabungan Pada PT. Bank Pembangunan Daerah (BPD) Sumatera Barat Cabang Utama Padang. https://doi.org/10.31219/osf.io/tf2bz 
Fernandes, Y. D., \& Marlius, D. (2018). Peranan Customer Service Dalam Meningkatkan Pelayanan Kepada Nasabah Pada PT. Bank Pembangunan Daerah Sumatera Barat Cabang Utama Padang. https://doi.org/10.31227/osf.io/wrh3p

Hidayati, R. R., \& Marlius, D. (2018). Aktivitas Promosi Dalam Meningkatkan Dana Pihak Ketiga Pada PT. Bank Perkreditan Rakyat (BPR) Batang Kapas Pesisir Selatan. https://doi.org/10.31227/osf.io/8dgqn

Irawan Ferry. 2010. Pengaruh Bauran Pemasaran Terhadap Keputusan Pembelian Ulang Rokok Sampoerna Avolution Pada Mahasiswa Fakultas Ekonomi UNP. Skripsi Tidak Diterbitkan. Padang: FE UNP.

Jamarnis, S., \& Susanti, F. (2019). Pengaruh Harga Dan Periklanan Melalui Internet Terhadap Keputusan Pembelian Produk Sabun Merek Lux Pada Mahasiswa STIE “KBP” Padang. https://doi.org/10.31227/osf.io/xz3d8

Kotler \& Amstrong. 2001. Prinsip-prinsip Pemasaran. Jakarta: Erlangga.

Kotler, Philip, (1997). Marketing Management: Analysis, Planning, Implementation, and Control. New Jersey: Prentice Hall Int. Inc. terjemah: Hendra Teguh, SE, Ak dan Ronny A. Rusly, SE, Ak. Jakarta: Prenhellindo. Edisi Indonesia, Jilid Indonesia, Jilid 1 dan 2.

Marlius, D. (2017). Keputusan Pembelian Berdasarkan Faktor Psikologis Dan Bauran Pemasaran Pada PT. Intercom Mobilindo Padang. Jurnal Pundi. Volume 1. No. 1. Hal. 57-66. https://doi.org/10.31575/jp.v1i1.9

Marlius, D. (2016). Pengaruh Bauran Pemasaran Jasa Terhadap Minat Nasabah Dalam Menabung Pada Bank Nagari Cabang Muaralabuh. https://doi.org/10.31227/osf.io/vdqgx

Mayliza, R. (2019). Pengaruh Citra Perusahaan (Corporate Image) Dan Penanganan Keluhan (Complaint Handling) Terhadap Loyalitas Pelanggan (Loyality) Natasha Skin Care Di Kota Padang. https://doi.org/10.17605/OSF.IO/DF9XJ

Mayliza, R. (2019). Pengaruh Kesadaran Merek, Asosiasi Merek Dan Perception Of Quality Terhadap Keputusan Pembelian Hospital Bed Merek Paramout Di PT. Aga Medika Utama Padang (Studi Kasus Rumah Sakit Umum Kota Padang). https://doi.org/10.17605/OSF.IO/VYQ4E

Priyanti,Y. Susanti, F. Aziz, N. (2017). Minat Beli Konsumen Toko Sepatu Bata Dipasar Raya Padang Dilihat Dari Sikap Dan Iklan. Jurnal Pundi, Vol. 01, No. 02

Rusvida, Lysa Eka. 2007. Pengaruh Produk Harga, Iklan Terhadap Keputusan Pembelian Konsumen Dalam Membeli Ulang Kripik Balado Christine Hakim 
Sebagai Oleh-Oleh Dari Kota Padang. Skripsi Tidak Diterbitkan. Padang: FE UNP.

Safitri, R. N., \& Marlius, D. (2017). Penerapan E-Banking Dalam Meningkatkan Jasa Dan Layanan Perbankan Di PT. Bank Rakyat Indonesia Cabang Padang. https://doi.org/10.31227/osf.io/gkv8t

Santoso, Purbayu Budi dan Ashari, 2011, Analisis Statistik dengan Microsoft Excel \& SPSS, ANDI, Yogyakarta.

Setiadi, Nugroho, J. 2003. Perilaku Konsumen, Konsep dan Implikasi Untuk Strategi dan Penelitian Pemasaran. Jakarta: Prenada Media.

Stanton, J. William. 1991. Prinsip-prinsip Pemasaran. Jakarta: Erlangga.

Sugiyono, 2003, Metodologi Penelitian Bisnis, CV. Alfa Beta, Bandung

Susanti, F. (2015). Pengaruh Bauran Promosi Terhadap Keputusan Klien Dalam Memilih Radio Carano Sebagai Media Promosi Iklan. https://doi.org/10.31227/osf.io/b9ws7

Susanti, F. (2014). Pengaruh Tarif Iklan Terhadap Pendapatan Pada PT. Radio Swara Carano Batirai Indah Batusangkar. https://doi.org/10.31227/osf.io/dy863

Susanti, F., \& Gunawan, A. C. (2019). Pengaruh Bauran Promosi Dan Harga Terhadap Keputusan Pembelian Produk Kosmetik Maybelline Di Kota Padang. https://doi.org/10.31227/osf.io/npjqh

Swasta dan Irawan (2005). Manajemen Pemasaran Modern. Yogyakarta: Liberty

Tjiptono, Fandy. 1997. Strategi Pemasaran. Yogyakarta: Penerbit Andi.

Umar, Husein. 2000. Metodologi Penelitian. Jakarta: Erlangga. 